\title{
KASHMIRI: A PHONOLOGICAL SKETCH
}

\author{
Farooq Ahamad Mir \\ farooq.lgst@gmail.com \\ Imtiaz Hasnain \\ imtiaz.hasnain@gmail.com \\ Aligarh Muslim University, India \\ Azizuddin Khan \\ khanaziz@iitb.ac.in \\ Indian Institute of Technology Bombay, India
}

Received November 25, 2018; Revised December 9, 2018; Accepted December 12, 2018

\begin{abstract}
Kashmiri is an Indo-Aryan language spoken predominantly in the state of Jammu and Kashmir, India and in some parts of Pakistan. Some phonological and morphological features of this language make it peculiar among Indo-Aryan languages. This write-up provides a phonological sketch of Kashmiri. The description of Vowels and Consonants is given in order to build a general idea of the phonological system of the language. The process of nasalization is phonemic in Kashmiri. The aim of this write-up is to describe and show all the phonological features of the language, particularly those that are uniquely found in this language. In addition, an attempt has been made to describe and explain the various phonological processes such as Palatalization, Epenthesis and Elision, which occur in Kashmiri. All such processes are described with appropriate examples and the data comprising of lexemes and sounds for examples is primary data used by the author who is a native speaker of the language. Given to the peculiar features of this language, the process of homonymy, which is homographic in nature, is described with appropriate examples.
\end{abstract}

Keywords: Kashmiri language, vowels, consonants, nasalization, phonological processes, homonymy.

Мір Фарук Агамад, Гаснаїн Імтіаз, Хан Азизуддин. Кашмірська мова: фонологічний нарис. Кашмірська мова - це індоарійська мова, якою здебільшого розмовляють у штатах Джамму й Кашмір у Індії, а також в деяких регіонах Пакистану. Деякі фонологічні та морфологічні відмінності цієї мови роблять ії особливою серед індоарійських мов. У статті подано фонологічний нарис кашмірської мови. Опис голосних і приголосних представлено з метою побудови загального уявлення про фонологічну систему досліджуваної мови. Процес назалізації в кашмірській мові $є$ фонемним. Метою цього дослідження $є$ опис і відображення всіх фонологічних особливостей мови, особливо тих, які $є$ унікальними в цій мові. Крім того, здійснено спробу опису й пояснення різних фонологічних процесів, таких як палаталізація, епентеза й елізія, які трапляються в досліджуваній мові. У цій статті всі згадані процеси описані з наведенням відповідних прикладів, а дані, що складаються 3 прикладів лексем і звуків, є первинними даними, які використані одним 3 авторів - носієм мови. Враховуючи особливі риси цієї мови, процес омонімії, який має гомографічний характер, описано за допомогою в ідпов ідних прикладів.

(C) Mir, Farooq Ahamad; Hasnain, Imtiaz; Khan, Azizuddin, 2018. This is an Open Access article distributed under the terms and conditions of the Creative Commons Attribution 4.0 International Licence (http://creativecommons.org/ licenses/by/4.0).

East European Journal of Psycholinguistics, 5(2), 32-41. https://doi.org/10.5281/zenodo.2583186 
Ключові слова: кашмірська мова, голосні, приголосні, назалізація, фонологічні прочеси, омонімія.

\section{Introduction}

Kashmiri is one of the twenty-eight Dardic languages of Indo-Aryan language family (Fussman, 1972; Grierson, 1973; Kachru, 1969; Koul \& Wali, 2006a; Mir, 2014a). It is the mother tongue of at least $65,54,369$ people in the state of Jammu and Kashmir, India (Census, 2011) and nearly 1,30,000 people speak it in Neelam and Leepa valleys of Azad Kashmir, Pakistan (Shakil, 2012). The natives of Kashmiri language call it /kə:Šur / or /kə:š ir/.Kashmiri is specified in the VIII Schedule of the Constitution of India as one of the scheduled languages and is also listed in the VI Schedule of the Constitution of Jammu and Kashmir (Kak, 2002a; Mir, 2014b).

The general word order of Kashmiri is SVO. However, it is the only language among Indo-Aryan languages that posseses verb-second (V2) word order also (Koul \& Wali, 2006b). Kashmiri has been reported to have many dialects based on social and regional classifications (Grierson, 1919; Kachru, 1969; Lawrence, 1895). Grierson (1919) however, claims that the true dialect of Kashmiri is Kistwari and other dialects such as Poguli, Siraji, Rambani are mixed dialects. Kashmiri is written in persio-arabic script. Earlier in ancient times it was written in Sharda script (Kak, 2002b; Koul, 1996).

\section{Phonological Sketch}

The phonemic system of Kashmiri has sixteen vowel sounds and twenty-eight consonant sounds. Vowels exhibit the process of Nasalization, which is phonemic in nature i.e. changes the meaning of the word (Grierson, 1919; Kak, 2002c).

\subsection{Vowels}

Vowels in Kashmiri are oral as well as nasalized. Koul (2002), reports that Kashmiri vowel system contains four peculiar vowel sounds, which are uniquely present in Kashmiri among other Indo-Aryan languages. These are the central vowels /i/, /i:/ and /ə/, /ə:/. However, /i / are /i:/ are particularly found in Kashmiri but /ə/ and /ə:/ are found in other Indo-Aryan languages also. Among these cenral vowels, the vowel $/ \dot{i}$ / contributes to the phenomenon of Palatalization. The Oral vowels are articulated by change in tongue position, tongue height and rounding of lips.

In total, there are sixteen (16) Oral vowel phonemes in Kashmiri that are given below in Table 1.

\subsection{Consonants}

There are (31) thirty-one consonants in Kashmiri. All the consonants, except palatal consonants, can be palatalized. The process of palatalization in Kashmiri is phonemic and not phonetic. The dental affricates $/ \mathrm{ts} /$ and $/ \mathrm{ts}^{\mathrm{h}} /$ are not found in 
Hindi, Urdu and many other languages in India.There are no voiced aspirated stops in Kashmiri. The consonants are given below in Table 2.

Table 1

Oral Vowels in Kashmiri

\begin{tabular}{|c|c|c|c|c|c|c|}
\hline & \multicolumn{2}{|c|}{$\begin{array}{c}\text { Front } \\
\text { Unrounded }\end{array}$} & \multicolumn{2}{|c|}{$\begin{array}{c}\text { Central } \\
\text { Unrounded }\end{array}$} & \multicolumn{2}{|c|}{$\begin{array}{c}\text { Back } \\
\text { Rounded }\end{array}$} \\
\hline High & & i: & & $\dot{\mathbf{i}}:$ & & u: \\
\hline $\begin{array}{l}\text { Lower } \\
\text { High }\end{array}$ & $\mathrm{i}$ & & $\dot{\mathbf{i}}$ & & $\mathrm{u}$ & \\
\hline Mid & e & e: & $\partial$ & ə: & o & o: \\
\hline $\begin{array}{l}\text { Lower } \\
\text { Mid } \\
\text { Lower }\end{array}$ & & & $a$ & & $\mathrm{~J}$ & כ: \\
\hline
\end{tabular}

Consonant Sounds in Kashmiri

\begin{tabular}{|c|c|c|c|c|c|c|c|}
\hline & Bilabial & $\begin{array}{l}\text { Labio- } \\
\text { dental }\end{array}$ & $\begin{array}{l}\text { Alveolar- } \\
\text { dental }\end{array}$ & $\begin{array}{l}\text { Retrof } \\
\text { lex }\end{array}$ & Palatal & Velar & Glottal \\
\hline $\begin{array}{l}\text { Stops } \\
\end{array}$ & & & & & & & \\
\hline $\begin{array}{l}\text { Voiceless } \\
\text { Unaspirated }\end{array}$ & $\mathrm{p}$ & & $\mathrm{t}$ & $t$ & & $\mathrm{k}$ & \\
\hline $\begin{array}{l}\text { Voiceless } \\
\text { As pirated }\end{array}$ & $\mathrm{p}^{\mathrm{h}}$ & & $\mathrm{t}^{\mathrm{h}}$ & $t^{h}$ & & $\mathrm{k}^{\mathrm{h}}$ & \\
\hline Voiced & $\mathrm{b}$ & & d & $\mathrm{d}$ & & $g$ & \\
\hline $\begin{array}{l}\text { Affricates } \\
\text { Voiceless } \\
\text { Unaspirated }\end{array}$ & & & ts & & $\check{c}$ & & \\
\hline $\begin{array}{l}\text { Voiceless } \\
\text { Aspirated }\end{array}$ & & & $\mathrm{ts}^{\mathrm{h}}$ & & $\check{c}^{h}$ & & \\
\hline $\begin{array}{l}\text { Voiced } \\
\text { Unaspirated } \\
\text { Nasals }\end{array}$ & & & & & $\mathrm{f}$ & & \\
\hline $\begin{array}{l}\text { Voiced } \\
\text { Fricatives }\end{array}$ & $\mathrm{m}$ & & $\mathrm{n}$ & & & $y$ & \\
\hline Voiceless & & V & $\mathrm{s}$ & & $\check{\mathrm{s}}$ & & $\mathrm{h}$ \\
\hline $\begin{array}{l}\text { Voiced } \\
\text { Lateral } \\
\text { (Voiced) }\end{array}$ & & & $\begin{array}{l}\mathrm{z} \\
\mathrm{l}\end{array}$ & & & & \\
\hline $\begin{array}{l}\text { Trill } \\
\text { (Voiced) }\end{array}$ & & & $\mathrm{r}$ & r & & & \\
\hline $\begin{array}{l}\text { Flap } \\
\text { (Voiced) }\end{array}$ & & & f & & & & \\
\hline $\begin{array}{l}\text { Approximan } \\
\text { ts (Voiced) }\end{array}$ & w & & & & $\mathrm{j}$ & & \\
\hline
\end{tabular}




\subsection{Nasalization}

The process of Nasalization is phonemic in Kashmiri (Kak \& Oveesa, 2009; Koul \& Wali, 2006) and the presence of a nasal vowel changes the meaning of an entire word. All oral vowels can be nasalized in Kashmiri except / / / and /ว:/. The process of Nasalization is shown below in Table 3 with appropriate examples.

Table 3

Oral and Nasal Vowels in Kashmiri with Examples and Gloss

\begin{tabular}{|c|c|c|c|c|c|}
\hline $\begin{array}{c}\text { Oral } \\
\text { Vowel }\end{array}$ & Example & Gloss & $\begin{array}{l}\text { Nasal } \\
\text { Vowel }\end{array}$ & Example & Gloss \\
\hline$/ \mathrm{i} /$ & miš & tooth pick & I & & hindu woman \\
\hline /i:/ & ti:r & Arrow & / & & minute \\
\hline /e/ & kel & Banana & I & & some \\
\hline /e:/ & le: $\mathrm{k}^{\mathrm{h}}$ & Write & / & & feel \\
\hline /i:/ & sì:t & With & /à:/ & k̂́:z & buttermilk \\
\hline /ít & tits $^{\mathrm{h}}$ & dusting cloth & 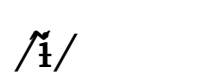 & กิżz & house \\
\hline$/ \partial /$ & gəd & Centre & /כ̃/ & gãd & knot \\
\hline /ə:/ & lə:r & Cucmber & /ã:/ & วิ:t & drupe \\
\hline$/ \mathrm{a} /$ & kar & Job & $/ \tilde{a} /$ & kãgir & fire pot \\
\hline /a:/ & a:ləv & Call & /âa:/ & kã:dur & baker \\
\hline$/ \mathrm{u} /$ & puz & Truth & I & & monkey \\
\hline /u:/ & lu:t $t^{\mathrm{h}}$ & Loot & / & $: \mathrm{t}^{\mathrm{h}}$ & knot on a scarf \\
\hline /o/ & god & Hole & I & & bouquet \\
\hline /o:/ & bo:j & Brother & / & & chinar tree \\
\hline
\end{tabular}

\section{Phonological Processes}

Phonological processes in Kahmiri have not been studied much. However the process of palatalization, which is a modification process, has been reported as one of the important and distinguishing feature of kashmiri phonology (Bhat, 2008a; Bhaskararao, et al., 2009). But there are also whole segment processes found in this language such as Epenthesis and Elision.

The phonological processes that occur in Kashmiri are discussed as follows:

\subsection{Palatalization}

Palatalization is one of the types of Modification Processes. The process of palatalization changes the manner or place of articulation of consonant sounds. In case of vowels, fronting or raising occurs due to the phonological change by palatalization. Bhaskararao, et al. (2009:5) quotes Ladefoged \& Maddieson (1996:363) while defining the process of palatalization as " ... the superimposition of 
a raising of the front of the tongue toward a position similar to that for /i/ on a primary gesture. Like labialization it is often more apparent at the release than at the formation of a primary constriction". In case of Kashmiri, the palatalization occurs at the word initial, medial and word final positions (Bhat, 2008b) and is prominently observed in speech. The palatalized forms are vivid at the word initial or final positions and at the word-medial positions it is often observed as the sound $/ \mathrm{j} /$. Moreover, the central unrounded vovel $/ \mathrm{i} /$ which is particularly found in Kashmiri and the approximant $/ \mathrm{j} /$ contributes to the process of palatalization in Kashmiri.

The process of palatalization induces inflectional changes in palatalized word forms for number and gender. For example:
a) $k u t^{\mathrm{h}}$
(singular) room
b) $\mathrm{kuit}^{\mathrm{h}} \mathbf{i}$
(plural) rooms
c) ko:n
(Masculine)one-eyed
d) kə:ni
(Feminine) one-eyed

The phenomenon of total palatalization is also observed in Kashmiri. For example:

e) miət (singular/feminine) round or ball shaped

f) meči (plural/feminine) round or ball shaped

Also, some examples of palatalization contributed by /j/ are as follows:
g) $\mathrm{p}^{\mathrm{j}}$ ən
(for plural)
will fall
h) djal
(plural)
barks of trees
i) ${ }^{\mathrm{j}} \mathrm{ul}$
(singular)
j) $\operatorname{par}^{\mathrm{j} u n}$
(singular)
eathquake
sieve

In some cases, the process of palatalization is phonemic in Kshmiri and may inflect a noun for plural number and or gender. For example:
k) mial
(appetite)
mial $^{j} \quad$ (fathers)
1) bəd
(big/ singular/ feminine) bəd
(big/plural/musculine)
m) tiat ${ }^{\text {h }}$
(dear/ singular/ feminine)
tiat $^{\text {hj }}$

It needs to be noted that the process of palatalization is same for all regional varities of Kashmiri. There will be pronunciation differences among the regional variants of a word but the place and manner of palatalizing vowel or approximant remains the same.

\subsection{Cluster Reduction}

Cluster Reduction is the phenomenon of simplifying a consonant cluster by deleting one of the immediate consonants. It means that the number of output segments in a speech shall differ from the input segments (Wheeler, 2005). In Kashmiri, the cluster reduction helps mark the regional dialectal variation, which gives rise to prestigious and non-prestigious language forms also. In all southern parts and some upper reaches of the northern parts of the valley of Kashmir, the 
consonant cluster is retained in speech where as cluster reduction is observed in central parts of Kashmir. For example:
a) / brjarr/ becomes / / ${ }^{j} \partial^{j} r /$
(cat/feminine/s ingular)
b) /tsra:r / becomes /tsa:r/
(prop.N/ singular)
c) /trakur/ becomes
/təkur/
(hard/musculine/singular)
d) /dror/
becomes
/dor/
(run/singular)

Thus, the CCVC pattern is reduced to CVC pattern. This type of cluster reduction can be also reffered to as diaglosic situation. It is often observed in Kashmir that if there is cluster reduction in a Kashmiri speech act, it is called prestigious form and the one which retains the consonant cluster is non-prestigious.

\subsection{Anaptyxis}

Anaptyxis is the phonological process in which a vowel sound is inserted in a word. It is the part of the process of Epenthesis (Crowley, 1997a; Pandey, 2018a). It is one of the common features of Kashmiri that a vowel is inserted between two consecutive consonants. Most often the vowel insertion occurs in a consonant cluster. This phenomenon is prominent in borrowed words where $/ \dot{\mathrm{i}} /$ is generally inserted between two consecutive consonants at the begining of a word. For example:
a) /skuil/
/sikul/ (school)
b) /plan/
/pilan/ (plan)
c) /sto:l/
/sits:l/ (stall)

Interestingly, if the insertion of $/ \mathrm{i} /$ is replaced by $/ \mathrm{\partial} /$ in above examples then it will give rise to a diaglossic variety called /pəha :r ikosur/ e.g:
d) /skuil/
/səku:l/ (school)
e) /plan/
/pəlan/ (plan)
f) /sto:l/
/sətว:1/ (stall)

This variety is called /pəha:rikosur/ which means the Pahari version of Kashmiri and the Pahari version is treated as the lower variety of the language. Although there exists nothing like /pəha:rikosur/ in Kashmiri but the variety is purely diaglossic.

The insertion of the vowel sounds in Kashmiri occurs mostly between the initial consonants of a word and at the word-final positions but not in the wordmedial positions. The insertion or addition of vowel at the end of the word gives rise to another epenthetic process called Paragoge which is discussed below.

\subsection{Paragoge}

Paragoge is realized as the phonological change in at the end of the word due to the insertion of a vowel. It is also part of the process of Epenthesis. It is found in Tamil and Kashmiri. In Tamil it is $/ \mathrm{u} /$ that is added to the word final position and in 
Kashmiri / $\mathbf{i} /$ is being added to word final positions. The insertion of $/ \mathbf{i} /$ at the word final position in Kashmiri is specifically inflectional in some cases and inflects a noun for number. For example:
a) $/ \partial \mathrm{l} /$
(singular) /əlì/
(plural)
pumpkin
b) $/ \partial \quad /$
(singular)
(plural)
eye
c) $/ \mathrm{kitab} /$
(singular) /kitabi/
(plural)
book
d) /na:w/
(singular) /na:wi/ (plural)
boats

Apart from being inflectional in fuction the process of addition of $/ \mathbf{i} /$ at the word-final position can be seen in most of the words in Kashmiri where it is not inflectional and is added as such. e.g:
e) /bəti/
(cooked rice)
f) /pati/ (afterwards)
g) /gotsi/ (shell of silk worm)
h) /dosti/ (friend)
i) /ə:ji:ni/ (mirror)

\subsection{Deletion or Elision}

Deletion or Elision is the process of deleting a phoneme or sound segment from a word. The deleted sound segment can be a vowel or a consonant. Depending up on the type of phoneme deletion, the phonological process of Elision can be Procope or Aphesis, Syncope, and Apocope. In Kashmiri, the Elision occurs more at word initial positions followed by word final positions. The elision in the middle of a word is also found in certain cases in this language. Following is the description of Aphesis, Syncope and Apocope in Kashmiri.

\subsubsection{Aphesis}

The process of Aphesis is commonly related to historical change of a language (Crowley, 1997b). It occurs at word-initial position, when a phonemic segement is deleted or ommitted at the beginning of a word. Some examples from Kashmiri are as follows:
a) /ələm/
(flag)
/ləm/
(heap)
b) /ələg/
(separate) /ləg/
(fine)
c) /tso:r/
(four) /orr/
(there)
d) $/ \mathrm{mo:l} /$
(father) /o:l/
(nest)

In Kashmiri the process of Aphesis occurs mostly in nouns. It retains the word category in most of the cases. 


\subsubsection{Apocope}

Apocope is the deletion or omission of a sound, usually an unstressed vowel, segment at word-final position (Chomsky \& Halle, 1968; Pandey, 2018b). In Kashmiri, this type of Elision occurs for consonants. Following are the examples from Kashmiri:
a) /o:nik/
(spectacles)
changes to /ə:ni/
(mirror)
b) /da:nd/ (bull)
changes to /da:n/
(oven)
c) /dənd/
(tooth)
changes to /dən/
(handle)

Kashmiri retains the word final vowel sounds however, drops or deletes the word-final consonants in the process of Elis ion. This is also called as final phoneme deletion.

\subsubsection{Syncope}

Syncope is the phonological process where a sound, which can be a vowel or a consonant, is omitted from the middle of a word. Usually, the process of syncope does not occur in Kashmiri. However, some instances of deletion of glottal $/ \mathrm{h} /$ are found in Kashmiri speech that can be treated as the process of syncope. For example:
a) /pãtshan/ (for fifty) /pãtsan/
b) /badšahis/(king's) /bads̃ais/
c) /šahza:d/ (prince) /šaza:d/

It needs to be mentioned here that the process of syncope usually does not occur in Kashmiri however, the examples given above are often observed in children who omit the glottal fricative $/ \mathrm{h} /$ in word-medial positions. This is referred to as their developmental error.

\section{Homophony}

Homophony is said to occur in a group of lexical items when they share the same morphological and or syntactic specifications (Leech, 1974). This means that these words may belong to similar or different word categories. These words have same pronunciation but different meanings. Interestingly, in Kashmiri this variation is opaque therefore the phenomenon of Homophony is Homographic. For example:
a) /ša:1/
(fox/ shawl)
b) /poš/
(flower/help)
c) $/ \mathrm{k}^{\mathrm{h}}$ ər $/$ (donkey/bug)
d) $/ \mathrm{k}^{\mathrm{h}} \mathrm{ur} /$ (undesirable / bald)
e) /və:r/ (vegetable garden / pot)
f) /də:r/ (window / beard)
g) /sum/ (hair style / bridge) 


\section{h) /son/ (gold /deep)}

Such homophones are same in speling and pronunciation but differ in meanings.

\section{Conclusion}

This write-up introduces the Kashmiri language as a language of Indo-Aryan family. It describes the basic phonological sketch of this language. The vowels and consonants present in the phonological system of this language has been shown. It has been described that this language contains a peculiar unrounded central vowel /ì $/$ which contributes to the process of Palatalization.The process of Nasalization which is phonemic in Kashmiri has been described with appropriate examples. Certain phonological processes in Kashmiri are described with appropriate examples. The phonological processes, which occur in Kashmiri have not been studied much however, the process of palatalization has been worked upon by many researchers. Palatalization is one of the important features of this language. The other processes such as Epenthesis and Elision have also been discussed.

Moreover, the process of Homonymy, which has been described in the writeup, is homographic i.e. a group of same pronuncing words have same spellings too.

\section{References}

Bhaskararao, P., Hassan, S., Naikoo, I. A., Wani, N. H., T. A., \& Ganai, P. A. (2009). A Phonetic Study of Kashmiri Palatalization. In M. e. Minegishi, Field Research, Corpus Linguistics and Linguistic Informatics (pp. 1-17). Tokyo: Tokyo University of Foreign Studies.

Bhat, R. N. (2008). Palatalization : a note on Kashmiri morphophonology. Retrieved 11 14, 2018, from Academia: https://www.academia.edu/6383970/Palatalization_A_Note_on_ Kashmiri_Morphophonology

Chomsky, N., \& Halle, M. (1968). The sound pattern of English. New York: Harper and Row . Crowley, T. (1997). An introduction to historical linguistics. Oxford: oxford University Press.

Fussman, G. (1972). Atlas linguistique des pariers Dardes et Kafirs. Paris: Ecole Francaise d'Etreme-Orient.

Grierson, G. A. (1919). Linguistic Survey of India. Calcutta: Superintendent Government Printing.

Grierson, G. A. (1973). A standard manual of Kashmiri language (Vol. 2). Rohtak: Light and Life Publishers.

Kachru, B. B. (1969). Kashmiri and other Dardic languages. (T. A. Sebeok, Ed.) Current Trends in Linguistics, 5, 284-306.

Kak, A. A. (2002). Languange maintenance and language shift in Srinagar. New delhi: Unpublished Phd dissertation, University of Delhi.

Kak, A. A., \& O. F. (2009). Nasality of Kashmiri vowels in Optimality theory. Nepalese Linguistics, 4, 61-68.

Koul, O. N. (1996). On the standardization of Kashmiri script. In S. I. Hasnain (Ed.), Standardization and Modernization: Dynamics of Language Planning (pp. 269-278). New Delhi: Bahri Publications.

Koul, O. N., \& Wali, K. (2006). Modern Kashmiri grammar. Springfield: Dunwoody Press.

Ladefoged, P., \& Maddieson, I. (1996). The sounds of the worls's languages. Oxford: Blackwell.

Lawrence, W. R. (1895). The valley of Kashmir. Srinagar: Kesar Publishers.

Leech, G. (1974). Semantics. Middlesex: Penguin Books. 
Mir, F. A. (2014). Acquisition of deixis among Kashmiri speaking children of 4-5 years of age. Department of Linguistics Aligarh Muslim University, Aligarh. Aligarh: Unpublished M.Phil Thesis.

Office of the Registrar General \& Census Commissioner, India. (2018, 10 12). Census,2011. Retrieved 11 12, 2018, from censusindia: http://www.censusindia.gov.in/2011Census/C16_25062018_NEW.pdf

Pandey, P. (2018). Types of Phonological Processes. Retrieved from e-Pathshala: http://ep gp.inflibnet.ac.in/epgpdata/uploads/epgp_content/linguistics/02.introduction_to_p honetics_and_phonology/21._types_of_phonological_processes-_i/et/7664_et_et_21.pdf.

Shakil, M. (2012). Academia. Retrieved 11 15, 2018, from Languages of erstwhile state of Jammu and Kashmir: a preliminary study: https://www.academia.edu/6485567/Languages_of_ Erstwhile_State_of_Jammu_Kashmir_A_Preliminary_Study_?auto=download

Wheeler, M. W. (2005). Cluster reduction: Deletion or Coalescence? Catalan Journal of Linguistics, 4, 57-82. Retrieved 11 2018, from https://www.raco.cat/index.php/Catalan Journal/article/view/39481 